\title{
0 acesso à justiça nas relações negociais públicas e privadas: a tutela dos direitos difusos e coletivos pela defensoria pública por meio da ação civil pública
}

\author{
Access to justice in private and public relations dealing: the protection of diffuse and \\ collective rights for public defense of public action
}

Angelita Maria Maders ${ }^{1}$

\section{Resumo}

Este artigo pretende contribuir para o debate que se trava no meio jurídico acerca da legitimidade da Defensoria Pública para a propositura da ação civil pública, no sentido de firmar entendimento favorável, o que poderá significar uma forma de ampliação do acesso à justiça a um número indeterminado de pessoas e, por sua vez, a redução da quantidade de demandas individuais questionando a mesma matéria, seja de natureza pública ou privada. As alterações legislativas que viabilizaram a propositura da ação civil pública pela Defensoria Pública significam, assim, um avanço à ampliação do acesso à justiça pela população. A constitucionalidade do dipositivo legal em questão, no entanto, é objeto de questionamento perante a Corte Suprema.

Palavras-chave: Acesso à justiça; Ação Civil Pública; Direitos difusos e coletivos; Legitimidade; Defensoria Pública.

\section{Abstract}

This article aims to contribute to the debate that rages on in the legal legitimacy of the Public Defender for the bringing of civil action in order to secure favorable understanding, which could mean a way of expanding access to justice for an indeterminate number people and, in turn, reducing the amount of individual claims challenging the same matter, whether public or private nature. The legislative changes that made possible the bringing of civil action by the Public Defender, so an advance to the expansion of access to justice by the people. The constitutionality of these question, however, is the subject of inquiry before the Supreme Court.

Keywords: Access to Justice; Public Civil Action; Diffuse and collective rights.; Legitimacy; Public Defender.

${ }^{1}$ Defensora Pública do Estado na Comarca de Santo Ângelo/RS, Doutora em Direito pela Universidade de Osnabrück, Alemanha, M estre em Gestão, Desenvolvimento e Cidadania pela Unijuí, Professora do M estrado em Direito da URI, bem como dos cursos de graduação em Direito na URI e na UNIJUÍ. 


\section{Introdução}

A ação civil pública, como um dos instrumentos à disposição de determinadas pessoas para a proteção dos direitos coletivos lato sensu, tanto na esfera dos negócios jurídicos públicos e privados, é considerada por muitos doutrinadores, processualistas, assim como juristas em geral como um mecanismo de ampliação e democratização do acesso à justiça. As reformas processuais realizadas a partir da décadas de 80 , nessa tangente, dentre elas a reformulação da legislação referente à tutela de direitos coletivos foram percebidas pela sociedade, que também pode constatar um amadurecimento nas políticas voltadas à garantia dos direitos e à produção legislativa, a exemplo da alteração da Lei № 7.347/85, mais precisamente do inciso II do artigo 5, pelo art. 30 da Lei 11.448/07, que inseriu a Defensoria Pública como legitimada para propositura da ação civil pública, e da promulgação da Lei Complementar no 132/2009, que ampliou as funções institucionais da Defensoria Pública em prol da comunidade ao alterar a Lei Complementar no 80/94.

Apesar de todos os avanços mencionados, no entanto, também ainda são possíveis de serem apontados os problemas que dificultam o acesso da população à justiça, em especial no que se refere às relações negociais, tanto privadas como aquelas que tem como uma das partes o próprio Poder Público. Vê-se, pois, que muito se tem a fazer para transformar o sistema jurídico brasileiro para garantir a efetividade dos direitos proclamados e vencer os obstáculos à construção de uma sociedade mais justa e igualitária, em especial no que se refere à garantia do acesso pleno à justiça para todos, por meio da instituição de mecanismos efetivos, voltados à proteção dos direitos declarados na Constituição Cidadã. Um desses instrumentos é a ação civil pública, por meio da qual se busca proteger direitos difusos e coletivos, isto é, os direitos de terceira dimensão, bem como a ação coletiva, destinada à proteção dos direitos individuais homogêneos. ${ }^{2}$

2 No que se refere à denominação ação civil pública, de se referir que o primeiro projeto de lei para a proteção dos direitos transindividuais não a consagrava, mas tratava-a como ação coletiva. 0 nome ação civil pública deve-se, portanto, ao segundo projeto enviado ao Congresso Nacional, o qual acabou sendo sancionado e transformou-se na Lei № 7.347/85, para diferenciá-lo da ação penal proposta pelo Ministério Público. Em não sendo ele seu único legitimado, a impropriedade do termo torna-se evidente, assim como também em razão de somente tutelar os direitos difusos e não os individuais homogêneos, para o qual seria incabível e a ação correta deveria ser a ação coletiva, nos termos do que hoje preconiza o CDC. No entanto, tanto na doutrina como na jurisprudência, o termo é empregado indistintamente, independentemente do autor da ação. Por isso, os termos ação civil pública e ação coletiva equivalem-se no presente artigo.

Revista de Direito Público, LondRINA, V. 6, N. 3, P. 21-38, OUT/ DEZ 2011. 


\section{Ação civil pública - aspectos gerais e históricos}

As ações para tutela coletiva de direitos ou para tutela de direitos coletivos são fruto da evolução social no que se refere à superação do individualismo e da percepção de que a ordem jurídica não pode se limitar a disciplinar a vida em sociedade tendo o indivíduo isolado como centro, já que este, embora dotado de um valor próprio e imensurável, está inserido e compromissado na comunidade em que vive, dela sendo dependente, assim como a comunidade é dele dependente. Na esteira desse processo de transformação alteraram-se as relações jurídicas e passou-se, gradativamente, a uma visão do homem como um ser social e nesse contexto deve ser considerado.

Ocorre que o sistema jurídico brasileiro, em especial o processual civil, estava moldado para a solução de conflitos individuais, tanto que o Código de Processo Civil de 1973 prevê, em seu artigo 60, que "ninguém poderá pleitear, em nome próprio, direito alheio, salvo quando autorizado por lei", o que não se coaduna com as regras pertinentes à propositura das ações coletivas. As regras vigentes sob a égide do referido diploma adjetivo não abarcavam as novas relações sociais que foram surgindo e, portanto, não norteavam a atuação jurídica na tutela coletiva de direitos ou dos direitos coletivos. Fez-se, pois, imprescindível a modernização do sistema jurídico, a fim de adequá-lo à nova realidade e à complexidade das relações sociais como as da sociedade em si.

Realizaram-se, então, diversas modificações legislativas, não somente no Código de Processo Civil, mas no modelo processual nele estabelecido, sobretudo a partir de 1985, com a promulgação da Lei no 7.347 (Lei da Ação Civil Pública), que assentou um marco para a tutela dos chamados direitos difusos e coletivos, embora sem defini-los, por se tratar de lei de conteúdo normativo eminentemente processual. Anteriormente, apenas por meio da ação popular permitia-se a tutela de direitos coletivos quando as autoridades públicas cometiam atos lesivos ao patrimônio público. (THEODORO JÚNIOR, 2008, p. 491).

A Constituição Federal de 1988, a seu turno, veio a implementar a possibilidade de substituição processual e, logo em seguida, no ano de 1990, o Código de Defesa do Consumidor foi criado como um instrumento de tutela coletiva de direitos individuais

ReVISTA de Direito Púbuico, LondRINA, V. 6, N. 3, P. 21-38, OUT/DEZ 2011. 
homogêneos.

Mas em que consiste essa ação judicial capaz de tutelar direitos em nome de terceiros? A própria Lei 7.347/85 deixa claro que ação civil pública constitui um mecanismo que visa a instrumentar demandas preventivas, reparatórias e cautelares de quaisquer direitos e interesses difusos e coletivos, nomeadamente "as ações de responsabilidade por danos morais e patrimoniais causados ao meio ambiente, ao consumidor, à ordem urbanística, a bens e direitos de valor artístico, estético, histórico, turístico e paisagístico, à ordem econômica, à economia popular e à ordem urbanística" (art. $1^{\circ}$ ). 0 Código de Defesa do Consumidor, no entanto, ampliou o horizonte de ações coletivas estabelecidos pela Lei da Ação Civil Pública, de modo que, atualmente, existem três diferentes tipos de ações coletivas: a) as relativas a direitos coletivos; b) as pertinentes a direitos difusos; e c) as referentes a direitos individuais homogêneos (THEODORO JÚNIOR, 2008, p. 494).

No que se refere à legitimidade ativa, ou seja, à exceção à regra prevista no artigo 60 do caderno adjetivo, o ordenamento pátrio adotou a legitimidade mista ou pluralista, já que não há exclusividade para propositura da ação civil pública, mas competência concorrente entre aqueles que constam no rol disposto no artigo 50 da Lei $7.347 / 85^{3}$, o que se dá na forma de substituição processual.

O legislador contemporâneo, no entanto, visando a democratizar ainda mais o instituto da ação civil pública, bem como para garantir a efetiva proteção dos direitos, por meio da Lei 11.448/07, ampliou a lista de legitimados ativos para propositura da ação civil pública, que ficaram assim dispostos:

Art. 5. Têm legitimidade para propor a ação principal e a ação cautelar:

I - o Ministério Público;

II - a Defensoria Pública;

III - a União, os Estados, o Distrito Federal e os Municípios;

IV - a autarquia, empresa pública, fundação ou sociedade de economia mista;

$V$ - a associação que, concomitantemente:

a) esteja constituída há pelo menos 1 (um) ano nos termos da lei civil;

b) inclua, entre suas finalidades institucionais, a proteção ao meio ambiente, ao consumidor, à ordem econômica, à livre concorrência ou ao patrimônio artístico,

3 A legitimidade ativa para as ações civis públicas ou coletivas em defesa de interesses difusos, coletivos, individuais homogêneos é considerada concorrente, autônoma e disjuntiva, já que cada um dos colegitimados pode propor a ação na forma de litisconsórcio com outros ou isoladamente (M AZZILI, 2001, p. 236).

Revista de Direito Público, LondRINA, V. 6, N. 3, P. 21-38, OUT/ DEZ 2011. 


\section{0 acesso à justiça nas relações negociais públicas e privadas: a tutela dos direitos difusos e coletivos pela defensoria pública por meio da ação civil pública}

estético, histórico, turístico e paisagístico. [...]

Mas os feitos legislativos vão além, pois, no ano de 2009, foi alterada a Lei Complementar n 80, de 12 de janeiro de 1994 - a Lei Orgânica da Defensoria Pública -, por meio da Lei Complementar no 132, na qual foi especificada como atribuição da referida Instituição a propositura de ações civis públicas para proteção de direitos difusos, coletivos e individuais homogêneos, o que, certamente, significa um avanço, uma porta aberta para o acesso pleno à justiça, uma vitória da cidadania, como se verá na sequência.

\section{Legitimidade da defensoria pública para a propositura de ações civis públicas}

Ao longo de sua jovem história ${ }^{4}$, a Defensoria Pública tem lutado para conseguir concretizar seu mister principal, ou seja, prestar assistência jurídica integral e gratuita aos necessitados ${ }^{5}$, nos termos preconizados no artigo 134. Essa mesma Constituição propôs-se a estabelecer um novo regime constitucional no País, fundado na democracia, e, para tanto, declarou em seu texto direitos e garantias fundamentais aos cidadãos, muitos deles ainda sem efetividade prática.

Ocorre que a sociedade brasileira continua a evoluir e o faz mais rapidamente do que a legislação, fato que é de conhecimento geral. Isso implica o aumento da complexidade das relações jurídicas, que não se limitam a conflitos particulares, mas envolvem a coletividade, tanto que os interesses tutelados são chamados de trans, supra ou metaindividuais ${ }^{6}$. Em decorrência do surgimento destes, houve uma alteração também na

4 Lembrar que a Instituição foi criada com a Constituição Federal de 1988, art. 134.

50 fato de a Constituição Federal utilizar a expressão assistência jurídica ao invés de assistência judiciária já significa uma importante inovação à população brasileira, pois aquela denota maior amplitude que esta, passando a compreender também o aconselhamento das partes, a consultoria e a informação jurídica, além da prática de atos jurídicos judiciais e extrajudiciais. Isso tudo para primar pela garantia da eficácia do princípio constitucional da igualdade ou isonomia substancial de acesso à justiça, com o intuito de alcançar a efetividade do Estado Democrático de Direito.

60 Código de Defesa do Consumidor trouxe a descrição jurídica do que se deve entender por direitos difusos, coletivos e, ainda, direitos individuais homogêneos, mais precisamente no art. 81, in verbis: Art. 81. A defesa dos interesses e direitos dos consumidores e das vítimas poderá ser exercida em juízo individualmente ou a título coletivo.

Parágrafo único. A defesa coletiva será exercida quando se tratar de:

I - interesses ou direitos difusos, assim entendidos, para efeitos deste Código, os transindividuais, de natureza

Revista de Direito Público, Londrina, V. 6, N. 3, P. 21-38, OUT/ DEZ 2011. 
relação processual, que, mais complexa, implicou a necessidade de ampliação dos mecanismos de acesso à justiça aos ditos "conflitos de massa".

Com a edição do Código de Defesa do Consumidor passou a predominar o entendimento de que existia legitimidade da Defensoria Pública para adoção das medidas que se referiam à defesa do consumidor, já que o dever absoluto do Estado na defesa destes é considerada cláusula pétrea (CF, art. 5ํ, XXXII).

Após anos de discussão, a Lei no 11.448/07 incluiu a Defensoria Pública entre os legitimados para a propositura de ação civil pública, o que, ao invés de acalmar os debates, gerou grande celeuma no meio jurídico, pois alguns juristas pretendem seja sua legitimidade limitada em razão da função precipuamente a ela atribuída, ou seja, a prestação de assistência jurídica integral e gratuita aos necessitados, na forma do que preceitua o artigo 5ำ, inciso LXXIV, da Constituição Federal.

Além dessa, a Lei Orgânica da Defensoria Pública, alterada em 07 de outubro de 2009, reforçou sua vocação como instituição voltada à defesa dos direitos humanos, inclusive na esfera extrajudicial e coletiva, tanto que nominada como "passaporte essencial à cidadania"7

No que se refere à função institucional da Defensoria Pública, de se destacar que ela é órgão independente da Administração Pública, com a função primordial de tutelar os interesses dos hipossuficientes, mas, em momento algum a Constituição Federal referiu ou qualificou a hipossuficiência ou a falta de recursos mencionada, de modo que não se pode restringi-la à hipossuficiência econômica, até porque, quando a Lei Complementar no 80/94, em seu artigo 4으, inciso Xl, refere-se à incumbência de "exercer a defesa dos interesses individuais e coletivos da criança e do adolescente, do idoso, da pessoa portadora de necessidades especiais, da mulher vítima de violência doméstica e familiar e de outros grupos sociais vulneráveis que mereçam proteção especial do Estado", não se refere a

indivisível, de que sejam titulares pessoas indeterminadas e ligadas por circunstâncias de fato;

II - interesses ou direitos coletivos, assim entendidos, para efeitos deste Código, os transindividuais, de natureza indivisível, de que seja titular grupo, categoria ou classe de pessoas ligadas entre si ou com a parte contrária por uma relação jurídica base;

III - interesses ou direitos individuais homogêneos, assim entendidos os decorrentes de origem comum.

7 Assim é e foi considerada no VIII Congresso Nacional dos Defensores Públicos, realizado em Porto Alegre, RS, de 3 a 6 de novembro de 2009.

Revista de Direito Público, LONDRINA, V. 6, N. 3, P. 21-38, OUT/ DEZ 2011. 


\section{0 acesso à justiça nas relações negociais públicas e privadas: a tutela dos direitos difusos e coletivos pela defensoria pública por meio da ação civil pública}

interesses de pessoas ou grupos carentes economicamente.

Para melhor esclarecer, de se referir que 0 artigo 4을 da Lei Complementar no 80/94 delimita a atuação dos Defensores Públicos, apresentando um rol de atribuições, o qual, no entanto, não é taxativo, pois outras atribuições poderão advir de outros textos legais, dentre eles, das constituições estaduais e de estatutos próprios, desde que compatíveis com sua finalidade.

A título de exemplificação, de se destacar que a Constituição do Estado do Rio de Janeiro, em seu artigo 179, estabelece que:

Art. 179 - A Defensoria Pública é instituição essencial à função jurisdicional do Estado, incumbindo-Ihe, como expressão e instrumento do regime democrático, fundamentalmente, a orientação jurídica integral e gratuita, a postulação e a defesa, em todos os graus e instâncias, judicial e extrajudicialmente, dos direitos e interesses individuais e coletivos dos necessitados, na forma da lei.

[...]

§ 3o - São funções institucionais da Defensoria Pública, dentre outras que lhe são inerentes, as seguintes:

[...]

e) ação civil pública em favor das associações necessitadas que incluam entre suas finalidades estatutárias a proteção ao meio ambiente e a de outros interesses difusos e coletivos;

[...]

Vê-se, pois, que aquele Estado já havia inovado no que tange às funções institucionais, pois, antes da promulgação da Lei 11.448, de 2007, já previa a atribuição de propor ação civil pública aos Defensores Públicos Estaduais.

No caso específico do Estado do Rio Grande do Sul, o Estatuto dos Defensores Públicos (Lei Complementar Estadual no 11.795, de 22 de maio de 2002) é claro ao trazer como incumbência da Defensoria Pública estadual, em seu artigo 3o, "a orientação jurídica e a assistência judiciária, integral e gratuita, dos necessitados, assim considerados na forma da lei, incluindo a postulação e a defesa, em todos os graus e instâncias, dos direitos e interesses individuais e coletivos, além das atribuições contidas na Lei Orgânica Nacional da Defensoria Pública (Lei Complementar № 80, de 12 de janeiro de 1994) e na Lei Complementar Estadual no 9.230, de 07 de fevereiro de 1991, alterada pela Lei Complementar Estadual no 10.194, de 30 de maio de 1994." O texto legal vai além e, no

Revista de Direito Público, Londrina, V. 6, N. 3, P. 21-38, OUT/ DEZ 2011. 
inciso VIII do parágrafo único, prevê o patrocínio "dos direitos dos consumidores que se sentirem lesados na aquisição de bens e serviços."

Nesse passo, de se observar, ainda, que do inciso III do artigo 40 da Lei Complementar no 80, em sua versão original, ou seja, do seio da expressão "patrocínio de ação civil", já se entendia favoravelmente à possibilidade de ajuizamento da ação civil pública para defesa de interesses difusos ou coletivos. A jurisprudência, por sua vez, ainda antes da edição da Lei no 11.448/2007, também firmava entendimento quanto à possibilidade de propositura da ação civil pública pela Defensoria Pública. Isso é o que se extrai das palavras do Ministro Sepúlveda Pertence proferidas na ADIN no 558-8-RJ:

[...] Também não consigo divisar, à vista desarmada, óbice constitucional à validade de que se incumba a Defensoria Publica do patrocínio judicial de ações voltadas por seu estatuto à proteção do meio ambiente e de outros interesses difusos, às quais a lei federal - como sucede com a L. 7347-85, endossada pela Constituição superveniente (CF, art. 129, parágrafo 1) - confere legitimação concorrente para as correspondentes ações civis [...] A Constituição Federal impõe, sim, que os Estados prestem assistência jurídica aos necessitados. Daí decorre a atribuição mínima da Defensoria Pública. Não, porém, o impedimento a que seus serviços se estendam ao patrocínio de outras iniciativas processuais em que vislumbre interesse social que justifique esse subsídio estatal.

Ao que se percebe, a legitimação ativa da Defensoria Pública para a propositura de ações coletivas, apesar da existência de entendimentos de que a Instituição não foi erigida à condição de legitimada ativa universal, provém da lei e da Constituição, tanto que tratada como missão institucional do Órgão. Do Projeto de Lei no 5.139/09 do Executivo, encaminhado ao Legislativo em 29.04.2009 e em trâmite no Congresso Nacional, com o qual se pretende regulamentar o chamado "Código de Processo Coletivo", percebe-se que está consagrada a legitimidade da Defenso ria Pública para a propositura da ação civil pública.

Não se pode olvidar, também, que o Estado tem 0 dever de conceder a todos 0 acesso à Justiça, pois seria discriminatório o ingresso em juízo viabilizado apenas aos que detêm situação econômica abastada, por exemplo. A função do Estado-Juiz é decidir os litígios e trazer a paz social nas relações intersubjetivas; logo, esta máxima estaria prejudicada se a maioria da população pobre não pudesse defender seus direitos. É por isso que a justiça deve ser gratuita, assim como a assistência jurídica, e facultada a todos, ainda mais quando o Estado concedeu a um de seus entes o monopólio da jurisdição. 


\section{0 acesso à justiça nas relações negociais públicas e privadas: a tutela dos direitos difusos e coletivos pela defensoria pública por meio da ação civil pública}

Esse também é o pensamento de Grecco Filho, ao afirmar que

[...] uma justiça ideal deveria ser gratuita. A distribuição da justiça é uma das atividades essenciais do Estado e, como tal, da mesma forma que a segurança e a paz pública, não deveria trazer ônus econômico aqueles que dela necessitam. Todavia, inclusive por tradição histórica, a administração da justiça tem sido acompanhada do dever de pagamento das despesas processuais, entre as quais se inclui 0 das custas que são taxas a serem pagas em virtude da movimentação do aparelho jurisdicional. (GRECCO FILHO, 1994, v. 1. p. 108)

Garantir 0 acesso à justiça a todos é, portanto, garantir a proteção e o exercício dos demais direitos ${ }^{8}$, bem como o princípio da igualdade material, isto é, dar vida ao princípio da isonomia preconizado na Carta Magna. É sair do formalismo das leis e efetivar a concretização dos direitos fundamentais consagrados na Constituição Federal, até porque 0 benefício da assistência jurídica gratuita não pode ser estendido tão-somente aos miseráveis economicamente, mas a todos aqueles que, em um momento de sua vida necessitam proteger seus direitos contra atos de terceiros ou do próprio Estado e não tenham condições para tanto, sejam técnicas, sejam financeiras para fazer frente à linguagem e aos procedimentos, bem como às despesas processuais e aos honorários advocatícios.

Fazendo-se uma ponderação mais alargada para justificar os argumentos aqui expostos, basta clamar pelo auxílio da hermenêutica e aplicá-la à realidade vigente para que se perceba que a Constituição Federal não se referiu à concessão da gratuidade da assistência jurídica apenas aos carentes de recursos financeiros, mas àqueles que comprovarem insuficiência de recursos, aos necessitados ${ }^{9}$, sem adjetivar estes como sendo financeiros, culturais, econômicos, técnicos, jurídicos[...], de modo que não cabe ao jurista fazer uma interpretação restritiva. Aliado a essa tese, não se poderia deixar de mencionar o número crescente de pessoas que, apesar de um nível de vida sensivelmente melhor em termos econômico-financeiros do que de muitos outros, considerados mais necessitados, em

8 É por isso que o direito ao acesso à justiça é chamado de direito charneira.

9 Importante relembrar que apenas um dos significados da palavra necessitado como adjetivo é de pobre, indigente, já que os demais referem tratar-se daquele que carece do necessário, que está obrigado pela necessidade. Ainda, o verbo "necessitar" é transitivo indireto, de modo que necessita de um complemento, pois a pessoa tem necessidade, carece ou precisa de algo, no caso em tela, necessidade de justiça, de solução para o conflito que a aflige.

Revista de Direito Público, Londrina, V. 6, N. 3, P. 21-38, OUT/ DEZ 2011 
uma concepção econômica da palavra, ainda assim vivam em condição de real pressão social, sujeitando-se à necessidade de ajustar os orçamentos domésticos ao máximo possível para sobreviver com um mínimo de dignidade. Sabiamente o legislador não olvidou essa categoria, tornando a norma um amplo e genérico instrumento capaz de alcançar-Ihes ao referir a Constituição Federal, no artigo 5으, inciso LXXIV, que "O Estado prestará assistência jurídica integral e gratuita aos que comprovarem insuficiência de recursos;".

Ademais, viabilizar 0 acesso à justiça de forma integral ${ }^{10}$ e gratuita a todos é equilibrar as relações entre os mais fracos (crianças, adolescentes, idosos, aposentados ou deficientes físicos, por exemplo) e os mais poderosos (aqui o Estado), do mesmo modo como se faz no direito consumerista, nos juizados especiais, dentre outros.

A par disso, não se pode deixar de considerar que a ação civil pública é um efetivo instrumento de acessibilidade à justiça, já que, com apenas uma demanda judicial pode-se beneficiar um número indeterminado de pessoas, as quais não necessitam despender gastos com custas processuais e honorários advocatícios em demandas individuais, já que os efeitos da decisão a ser proferida naquela produz efeito erga omnes. Quando esta ação é proposta pela Defensoria Pública, pode-se dizer que este órgão está cumprindo com sua missão institucional, que é a garantia da prestação de assistência jurídica integral e gratuita, sem discriminações de qualquer ordem, e garantindo a efetividade constitucional.

Evidente, pois, a legitimidade da Defensoria Pública para a propositura de ações coletivas, mesmo que dentre os beneficiados com a condenação haja cidadãos não hipossuficientes economicamente, tanto que eventual benefício a cidadãos nãohipossuficientes (no sentido econômico) com a propositura de uma ação civil pública pela Defensoria Pública não poderá impor prejuízos à parcela de cidadãos carentes que dela dependem para acessar o Poder Judiciário em caso de prevalecer o entendimento de que a prestação jurídica integral e gratuita deva ser somente fundada em critérios financeiros.

Outrossim, a atuação difusa por parte da Defensoria Pública prestigia a otimização racional do próprio Poder Judiciário, uma vez que a molecularização da demanda inviabiliza a propositura de infinitas ações individuais, o que corresponde à atomização da tutela propalando o mesmo tema, evitando-se decisões contraditórias, sempre incompreensíveis 


\section{0 acesso à justiça nas relações negociais públicas e privadas: a tutela dos direitos difusos e coletivos pela defensoria pública por meio da ação civil pública}

para os não iniciados na jurisprudência, portanto, à maioria da população, permitindo o desafogamento dos Tribunais, gerando credibilidade ao próprio sistema de justiça.

Apesar de tudo isso, houve o ajuizamento da ADIn no 3.943 pela Associação Nacional do Ministério Público - CONAM P contra a alteração da lei que trata da Ação Civil Pública. Ela se encontra em fase inicial e, portanto, sem decisão, ainda que liminar, de modo que não provocou alteração no que tange à vigência do disposto no artigo 5ํ, inciso II, da Lei no 7.347/85, com a redação dada pela Lei $\mathrm{n}$ - 11.448/07, tanto que muitas ações foram ajuizadas pela Defensoria Pública. ${ }^{11}$

Como se percebe, 0 debate não é recente ${ }^{12}$ e ainda está longe de acabar. Somente a título de elucidação, utilizando-se os argumentos expostos nas ações civis públicas movidas pela Defensoria Pública do Estado em 30 Comarcas contra aumentos abusivos das mensalidades dos planos de saúde em razão do adimplemento da idade, para garantia do disposto no Estatuto do Idoso, ressalta-se que o tema passou pela análise dos M inistros do $\mathrm{E}$. Supremo Tribunal Federal, no julgamento da Ação Declaratória de Inconstitucionalidade 558$8 / R J^{13}$.

11 A título de exemplo, tramitam em diversas comarcas do Estado do Rio Grande do Sul diversas ações civis públicas ajuizadas pela Defensoria Pública para a tutela de direitos dos consumidores, na área da saúde, da moradia, educação, transporte, regularização fundiária, dentre outras para proteção de crianças e idosos.

12 Embora a Lei da Ação Civil Pública exista há 25 anos, muitas questões pendem de discussão quanto à própria legitimidade do Ministério Público no que se refere à proteção dos direitos individuais homogêneos, bem como à legitimidade dos entes federados para determinadas matérias (pertinência temática).

13 Ocorre que no ano de 1991, o Procurador-Geral da República, atendendo representação do ProcuradorGeral de Justiça do Rio de Janeiro e da Associação do Ministério daquele Estado, propôs Ação Direita de Inconstitucionalidade (ADIn 558-8/RJ) contra 0 artigo $176^{7}$ da Constituição fluminense, sob a alegação de que a atribuição da Defensoria Pública para a defesa dos interesses coletivos representaria "estorvo à atuação do M inistério Público do Estado".

O Relator, Eminente Ministro Sepúlveda Pertence, no julgamento do pedido de suspensão cautelar de dispositivos, negou "consistência jurídica às argüições" feitas, e o pedido de suspensão liminar do referido artigo, em sede de medida cautelar, foi indeferido. A ação, todavia, ainda pende de julgamento final.

Entendeu ainda o Douto Ministro que a vocação da Instituição Defensoria Pública, de prestação de orientação jurídica aos necessitados, constitui "atribuição mínima compulsória" do Órgão, e jamais poderá significar um impedimento para sua atuação, especialmente quando esta é norteada pela relevância social do interesse tutelado, que justifica a intervenção estatal. Nesse sentido, transcreve-se trecho do voto do Ministro Pertence:

[...] 25. A Constituição Federal impõe, sim, que os Estados prestem assistência judiciária aos necessitados. Daí decorre a atribuição mínima compulsória da Defensoria Pública. Não, porém, o impedimento a que os seus serviços se estendam ao patrocínio de outras iniciativas processuais em que se vislumbre interesse social que justifique esse subsídio estatal.

Revista de DiReITo Público, LONDRINA, V. 6, N. 3, P. 21-38, OUT/ DEZ 2011 
Ainda, em sendo a ação civil pública um importante mecanismo de defesa dos direitos transindividuais, não haveria motivos para que o legislador não inserisse a Defensoria Pública no rol dos legitimados para propô-la, ainda mais se considerados os princípios da instrumentalidade, da economia processual e da eficiência. Não se pode deixar de mencionar, nesse norte, que a ampliação dos legitimados para a propositura das ações coletivas somente poderá alargar a abertura do sistema judiciário aos cidadãos e, portanto, sua participação na interpretação legislativa e na vida social.

No que se refere aos direitos difusos, de se destacar que eles são de sujeitos indeterminados, de modo que não se poderia precisar sua condição econômica. Exigir-se, portanto, a demonstração de que somente os interesses dos necessitados economicamente estão sendo atendidos pela ação coletiva proposta pela Defensoria Pública é totalmente equivocado, pois esta ação objetiva justamente proteger um bem ou valor jurídico universal, ou seja, que pertence a todos, dentre os quais estão incluídos os miseráveis e os pobres.

A divergência parece ter sido superada, no entanto, no que se refere aos direitos individuais homogêneos, já que estes são divisíveis e os beneficiários da ação identificáveis, de modo que, se considerados carentes, estaria preenchido o critério que se pretende como legitimador da atuação da Defensoria Pública.

De se recordar, ainda, que a lei que regula a ação civil pública consagra uma fase processual cognitiva e outra executiva. Na primeira, independe a questão da legitimidade ordinária ou extraordinária, de modo que não haveria porque impedir a atuação da Defensoria Pública em prol da coletividade, mesmo que dentro desta existam pessoas que não se enquadrariam no modelo de hipossuficiência propugnado como sendo aquele do público alvo da atuação da Defensoria Pública, já que isto seria verificado na fase executória, quando referidas pessoas teriam de buscar, por meio de procuradores constituídos, a

26. Não me impressiona, de sua vez, a increpação de que as atribuições aí deferidas à Defensoria Pública implicaram invasão de áreas de atuação reservadas ao M inistério Público [...]". (grifo nosso)

Outrossim, de enfatizar que, por ocasião do ajuizamento da referida ADIn n.o 3.943, a Associação Nacional dos Defensores Públicos - ANADEP, admitida como "amicus curiae" na demanda, solicitou parecer da llustre Professora ADA PELLEGRINI GRINOVER acerca da legitimidade da Defensoria Pública para a propositura de ações coletivas de consumo.

Em suas considerações, a llustre Professora aduz, em relação à iniciativa da CONAM P:

"Fica claro, assim, que o verdadeiro intuito da requerente, ao propor a presente ADIN, é simplesmente o de evitar a concorrência da Defensoria Pública, como se no manejo de tão importante instrumento de acesso à justiça e de exercício da cidadania pudesse haver reserva de mercado."

Revista de Direito Público, LondRINA, V. 6, N. 3, P. 21-38, OUT/ DEZ 2011. 


\section{0 acesso à justiça nas relações negociais públicas e privadas: a tutela dos direitos difusos e coletivos pela defensoria pública por meio da ação civil pública}

execução da sentença proferida na fase de conhecimento.

Para a solução do impasse, contudo, deve-se analisar não somente a lei, mas o conjunto de princípios que regem o sistema jurídico como um todo, uma vez que são eles a vigas desse sistema por expressarem o "querer popular" (ATALIBA, 1985).

\section{A defensoria pública e a proteção dos direitos coletivos e difusos como efetivação do acesso à justiça}

Para se seguir com a explanação do tema que se propôs no presente artigo devese afirmar, como feito alhures, que a Defensoria Pública tem legitimidade para a defesa dos direitos difusos e coletivos, mesmo que dentre os beneficiados com a referida demanda judicial existam pessoas não consideradas necessitadas, no aspecto econômico-financeiro.

Afirmação dessa ordem decorre do fato de que a defesa dos interesses dos hipossuficientes econômicos não pode depender, ou seja, submeter-se ou sujeitar-se à propositura da ação por outros legitimados que não aquele que constitucionalmente tem legitimidade para sua defesa - a Defensoria Pública, para então serem beneficiados reflexivamente, quando a Defensoria Pública tem por missão institucional a garantia do acesso à justiça. Este, aliás, deve ser um dos pilares do sistema democrático brasileiro para que se possa alcançar a efetividade constitucional.

Além disso, a propositura de uma demanda coletiva diminui ou evita a propositura de inúmeras ações individuais ${ }^{14}$, o que, por sua vez, torna o processo mais célere e eficiente, além de evitar a ocorrência de decisões contraditórias. Isso vem em proveito não somente do cidadão individualizado, mas da própria ordem jurídica. Deveras, vale observar que, raramente, os direitos difusos seriam levados isoladamente a Juízo, sobretudo porque

140 ingresso de uma enxurrada de ações individuais também é chamado no texto do artigo de atomização da tutela judicial. Importante destacar, no entanto, que, na tutela coletiva, em uma única ação é discutido o direito de um grupo, classe ou categoria de pessoa, enquanto que na defesa individual, as ações judiciais dos lesados são pulverizados, e levam a julgamentos contraditórios, o que ocasiona desprestígio para a administração da Justiça e leva muitos lesados a abandonar a desistir do acesso individual à jurisdição. A defesa judicial coletiva faz-se por meio de legitimação extraordinária, pois o autor da ação civil pública ou coletiva defende mais do que o direito próprio à reintegração da situação jurídica violada, mas interesses individuais alheios, não raro até mesmo divisíveis, que são compartilhados por grupo, classe ou categoria de pessoas (M AZZLI, 2001. p. 45).

Revista de Direito Público, LondRina, V. 6, N. 3, P. 21-38, OUT/ DEZ 2011. 
dificilmente alguém iria chamar a si o ônus de defender tais aspirações contra litigantes experientes, chamados "litigiantes habituais", despendendo com custas e honorários advocatícios para tanto.

0 auxílio ao necessitado não pode ser considerado o limite da atuação da Defensoria Pública, embora seja sua atividade principal, pois um conceito moderno de necessitado engloba mais do que o de despossuído econômico, mas de "todos os tipos de hipossuficiência que se tornam um óbice para o acesso do indivíduo à justiça" (MARTINS, 2009), ou seja, o hipossuficiente jurídico ${ }^{15}$, sob pena de se confirmar a máxima de que, para muitos, a justiça é apenas uma quimera acadêmica.

As normas jurídicas devem ser analisadas como um todo sistêmico sob a ótica dos princípios maiores que regem o sistema jurídico, pois todas as normas relacionadas à assistência judiciária, ao acesso à justiça e à proteção de direitos coletivos são dotadas de caráter integralista, isto é, têm por fim dar efetividade integral à prestação jurisdicional.

Por meio de uma interpretação sistêmica não se pode concluir que o teor do artigo 134 da Constituição Federal limita a atuação da Defensoria Pública aos carentes econômicos, até porque tal restrição colidiria com outra norma constitucional que refere que a todos é garantido o direito de defesa, tanto que, na seara criminal, sempre que a parte apresentar-se sem advogado é-lhe nomeado Defensor Público, independentemente de sua situação econômico-financeira. Além disso, os Defensores Públicos exercem a função de curadores especiais em processos judiciais que envolvam interesses de pessoas ausentes, citadas por edital e ou incapazes, como é o caso das interdições, quando o Ministério Público propõe a ação, função para a qual não é analisada a situação econômico-financeira da pessoa física ou jurídica, cujos interesses se está a tutelar processualmente.

A legitimidade de atuação da Defensoria Pública em favor dos direitos humanos, do interesse social ${ }^{16} \mathrm{e}$, portanto, das pessoas que integram a comunidade, mesmo daquelas

15 Assim considerado pela Profa. Ada Pellegrini Grinover ao asseverar que: "No que respeita à assistência judiciária, seu próprio conceito se renovou, tomando uma dimensão muito mais ampla [...] assim a assistência judiciária aos economicamente mais fracos foi estendida aos hipossuficientes jurídicos (Acesso à Justiça e o Código de Defesa do Consumidor. (GRINOVER, 1996. p. 116-117).

16 Interesse social "é 0 interesse que reflete 0 que esta sociedade entende por 'bem comum'; 0 anseio de proteção à res publica; a tutela daqueles valores e bens mais elevados, os quais essa sociedade, espontaneamente, escolheu como sendo os mais relevantes." (MANCUSO, 2000, p. 27).

Revista de Direito Público, LondRINA, V. 6, N. 3, P. 21-38, OUT/ DEZ 2011. 
que não sejam necessitadas, como nos casos supracitados, é conhecida e aceita no ordenamento jurídico, tanto que garantida por previsão constitucional e infraconstitucional, e sem que, para tanto, fosse proposta qualquer ação direita de inconstitucionalidade.

$\mathrm{Na}$ prática pode ocorrer, também, de serem violados direitos que possuam natureza tanto individual, divisível, como coletiva ou indivisível, como é o caso do direito à saúde, à educação, ao transporte coletivo, dentre outros. A propositura da ação civil pública pela Defensoria Pública iria beneficiar os cidadãos individualmente, mas também a coletividade, ou seja, a soma de interesses individuais que estejam sendo violados e sofrendo prejuízos, comprometendo "os valores comunitários especialmente privilegiados pelo ordenamento jurídico" (ZAVASCKI, 1995, p. 159).

Outrossim, a Defensoria Pública é órgão essencial à função jurisdicional e mais, é 0 "passaporte para a cidadania" e instrumento de concretização de uma sociedade mais justa e solidária, de construção do Estado Democrático de Direito. Sua atuação não se limita à judicial, mas também é administrativa, extrajudicial e supraindividual, sempre com primado nos objetivos da República Federativa do Brasil, em especial na dignidade da pessoa humana.

Restringir a autuação de tão importante órgão na administração da justiça é ferir os direitos mais comezinhos e, portanto, atentar contra a própria democracia idealizada para o Brasil na Constituição Cidadã, na qual também é assegurado a todos, sem distinção, a igualdade como valor supremo de uma sociedade livre, justa e fraterna, comprometida com a solução pacífica dos conflitos.

De concluir, portanto, que a legitimação ativa da Defensoria Pública para a propositura da ação civil pública não é subsidiária, mas concorrente com os demais legitimados, tanto que pode se litisconsorciar com os outros legitimados, bem como, extraordinária, no termos do artigo 6 o do Código de Processo Civil. Eventual existência de indivíduos não hipossuficientes dentre os beneficiados com o resultado da demanda não retira a legitimidade ad causam do órgão, pena de ferir-se o primado da acessibilidade plena à justiça. 


\section{Conclusão}

0 Estado e o Direito devem evoluir para efetivamente garantir o reconhecimento e a proteção dos direitos dos homens, como preconizado por Norberto Bobbio (1992), pois somente assim se poderá assegurar a solução pacífica dos conflitos e caminhar rumo à concretização da democracia.

A proteção dos direitos meta, trans ou supraindividuais em juízo, sejam eles inerentes à esfera negocial pública ou privada, por parte da Defensoria Pública representa um considerável avanço no ordenamento jurídico pátrio, pois implica a ampliação do acesso à justiça, já que o modelo tradicional de tutela individual não consegue, em uma sociedade complexa como a atual, solucionar os conflitos existentes. Além disso, demonstra que a sociedade brasileira está caminhando para dar efetividade aos direitos consagrados na Constituição Federal, vencendo os obstáculos do acesso à justiça propalados no estudo realizado por Cappelletti e Garth (1988).

A Defensoria Pública, como instituição de foro constitucional, não deve ser tida apenas como instrumento de enfrentamento do primeiro obstáculo ao acesso à justiça por eles levantados - o econômico. M ais do que isso, para a concretização de seu mister já lhe foi atribuída, axiológica e organicamente, como visto, a nobre missão de desfazer todos os demais obstáculos, dentre eles o segundo, referente à defesa dos direitos e interesses difusos e coletivos (tema deste artigo) e o terceiro, que é proporcionar outros meios alternativos de justiça, para o que deve, urgentemente, ser melhor estruturada. Dentre esses mecanismos, não se pode deixar de mencionar a mediação e a arbitragem, sendo a primeira já em prática em diversos escritórios da Instituição, em especial no que se refere ao Direito de Família e às relações negociais de natureza consumerista e civil.

No caso da mediação, como uma forma extrajudicial de solução de conflitos, temse como regra uma resposta mais rápida e eficiente aos conflitos, além de mais democrática, pois a resposta é dada pelos próprios envolvidos. Outrossim, ela enseja a desjudicialização dos conflitos, o que tem ocorrido, inclusive durante as investigações preliminares dos fatos noticiados e que ensejariam a propositura de uma ação civil pública, mas que podem conduzir a um consenso entre as partes, quando, então, firma-se um termo de compromisso em respeito aos direitos dos cidadãos.

Revista de DiReITo Público, LONDRINA, V. 6, N. 3, P. 21-38, OUT/ DEZ 2011. 
Portanto, a alteração legislativa que aumentou o número de legitimados para a propositura da ação civil pública, em especial por incluir neste a Defensoria Pública, merece aplausos, pois ampliou o espectro de defesa dos cada vez mais complexos interesses e direitos transindividuais emergentes em diferentes campos da atuação jurídica, fazendo valer 0 aspecto de que 0 acesso à justiça não implica somente efetividade ou garantia dos direitos individuais, mas também dos coletivos.

\section{Referências}

ATALIBA, Geraldo. República e Constituição. São Paulo: Revista dos Tribunais, 1985.

BOBBIO, Norberto. A era dos direitos. Trad. Carlos Nelson Coutinho. Rio de Janeiro: Campus, 1992.

BRASIL. Supremo Tribunal Federal. ADIN n. 558-8-RJ, Req: Procuradoria Geral da República, Requer: Assembleia Legislativa do ERJ, Rel. M in. Sepúlveda Pertence. RTJ 146-435. Disponível em: «www.stf.gov.br/jurisprudencia/jurisp.asp >. Acesso em: 18 dez 2009.

. Constituição (1988). Constituição da República Federativa do Brasil. 17. ed. São

Paulo: Saraiva, 2009.

CAPPELLETTI, M auro; GARTH, Bryant. Acesso à Justiça. Tradução de Ellen Gracie Northfleet. Porto Alegre: Fabris, 1988.

GARCIA, Emerson. A Legitimidade da Defensoria Pública para o Ajuizamento da Ação Civil Pública: Delimitação de sua Amplitude. Disponível em: «ttp://www.conamp.org.br/ index.php?a=mostra_artigos.php\&ID_M ATERIA=1255>. Acesso em: 18 dez 2009.

GRECCO FILHO, Vicente. Direito Processual Civil Brasileiro. 9. ed. São Paulo: Saraiva, 1994. v.1.

GRINOVER, Ada Pellegrini. O Processo em evolução. Rio de Janeiro: Forense Universitária, 1996.

M ANCUSO, Rodolfo de Camargo. Interesses difusos. 5. ed. São Paulo: RT, 2000.

M ARTINS, Raphael M anhães. A Defensoria Pública e 0 acesso à justiça. Disponível em: বttp://www.cjf. gov.br/revista/numero30/artigo 05.pdf>. Acesso em: 29 dez 2009.

Revista de Direito Púbuco, Londrina, V. 6, N. 3, P. 21-38, OUT/ DEZ 2011. 
M AZZLLI, Hugo Nigro. A defesa dos interesses difusos em juízo. 13 ed. São Paulo: Saraiva. 2001.

M EIRELLES, Hely Lopes. Mandado de Segurança, Ação Popular, Ação Civil Pública, Mandado de Injunção, "Habeas Data". 18. ed. atual. São Paulo: M alheiros, 1997.

M ORAES, Guilherme Braga Pena de. Assistência Jurídica, Defensoria Pública e o Acesso à Jurisdição no Estado Democrático de Direito. Rio de Janeiro: Lúmen Júris, 1997.

QUEIROZ, Cláudia Carvalho. A legitimidade da Defensoria Pública para propositura da ação civil pública. Disponível em: বhttp://jus2.uol.com.br/doutrina/texto. asp?id=7566>. Acesso em: 18 dez. 2009.

THEODORO JÚNIOR, Humberto. Curso de Direito Processual Civil: procedimentos especiais. Rio de Janeiro: Forense, 2008. $3 \mathrm{v}$.

ZAVASCKI, Teori Albino. Processo Coletivo. Tutela de Direitos Coletivos e Tutela Coletiva de Direitos. 2. ed. rev. e atual. São Paulo: Ed. Revista dos Tribunais, 2007.

. Defesa de direitos coletivos e defesa coletiva de direitos. Revista Forense, v. 91, n. 329, p. 147-160, jan./mar. 1995.

Artigo recebido em:

26 jun. 2011

Artigo aprovado em: 27 out. 2011 